\title{
„FELKÉSZÜLÉS (EGYÜTT) A XXI. SZÁZAD KIHÍVÁSAIRA” CÍMÜ KIADVÁNY BEMUTATÁSA (RECENZIÓ)
}

\section{Szerzők:}

Dr. Mező Katalin

Debreceni Egyetem

Első szerző e-mail címe: kata.mezo1@gmail.com

\section{Lektorok:}

Dr. Tariszka Éva

Budapesti Gazdasági Egyetem

Dr. Koncz István

Professzorok az Európai Magyarországért

Egyesület

Mező Katalin (2018): „Felkészülés (együtt) a XXI. század kihívásaira” című kiadvány bemutatása (recenzió). Különleges Bánásmód, IV. évf. 2018/2. szám, 79-82. DOI 10.18458/KB.2018.2.79

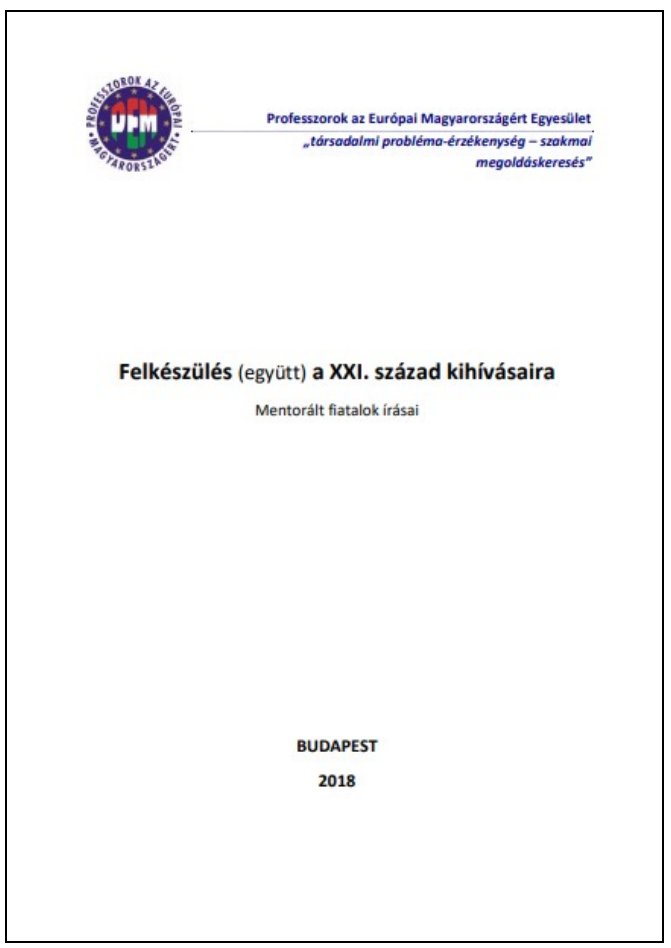

A recenzió alapjául szolgáló mü bibliográfiája:

Kemény László, Koncz István és Szova Ilona (szerk.)(2018): Felkészülés (együtt) a XXI. század kihívásaira. Mentorált fiatalok írásai. Professzorok az Európai Magyarországért Egyesület, Budapest. 194 oldal.

Kulcsszavak: innováció, tehetség

Diszciplinák: pedagógia, pszichológia

Bibliography of the subject of this recension:

Kemény László, Koncz István és Szova Ilona (szerk.)(2018): Felkészülés (együtt) a XXI. század kihívásaira. Mentorált fiatalok írásai. Professzorok az Európai Magyarországért Egyesület, Budapest. 194 oldal.

Keywords: innovation, talent

Disciplines: pedagogy, psychology

„Professzorok az innovatív fiatalokért” címmel nyert és valósított meg NTP-PKTF-170016. azonosítószámú pályázatot a Professzorok az Európai Magyarországért Egyesület 2017/2018-ban az Emberi Erőforrás Támogató és a Nemzeti Tehetség Program segítségével megvalósított pályázati kiírás keretében. A projekt határokon is átívelő módon nemcsak Magyarország, hanem Románia, Szerbia, Szlovákia magyar fiataljait is megszólította a következő célcsoportokra fókuszálva: 6 mentor 12 hazai fiatal (18-35 éves korosztálybeliek) számára nyújtott innovációra történő felkészítést, az innovációval kapcsolatos programsorozatot és konferencia lehetőséget, valamint arra vonatkozó felkészítést, hogy a 
bevont fiatalok miként tarthatnak innovációval kapcsolatos foglalkozásokat több, mint 200 középiskolás számára a program során.

E projekt egyik produktuma Kemény László, Koncz István és Szova Ilona szerkesztésében megjelent „Felkészülés (együtt) a XXI. század kihívásaira” címü szerkesztett kiadvány, melynek tanulmányait a programba bevont - részben mentorált, részben önálló kutatást végző és tréninget tartó 35 éves kor alatti fiatal tehetségek alkották. A kötetet a fiatalok által készített posztereket tartalmazó DVD egészíti ki, amelyben Tóth Máté digitális prezentációja is közzétételre került.

$\mathrm{Az}$ innováció rendkívül szerteágazó jelenségvilága magában hordozza annak interdiszcipplináris kutatási, elemzési, felhasználási lehetőségeit is. Közelíteni lehet e téma felé az innovátorok és specifikus alcsoportjaik (mint például sajátos nevelési igényü és/vagy tehetséges személyek csoportjai), vagy intra-/interperszonális jellegzetességeik felöl. Egy újabb megközelítési lehetőség a tanulás és innováció kapcsolatrendszerére koncentrálhat. Vagy akár a munka világa felől is megragadható az innováció témaköre.

A kiadványban megjelenő témák kiválóan reprezentálják a tehetség (s az innováció témakör) sokszínűségét. A szerzők között volt, aki a Nemzeti Köznevelésről szóló 2011. évi CXC. törvény szerinti különleges bánásmódot igénylö (többek között sajátos nevelési igényü és/vagy tehetséges) gyermekekre, tanulókra, s későbbi felnőttkori világukra fókuszált. Babik Tamás (2018) például a „többségi társadalom” tagjai részére fogyatékosság-specifikus tréningek tartásáról, míg Csepregi Csilla (2018) a sajátos nevelési igényü fiatalok magyarországi továbbtanulási lehetőségeiről értekezett. A tehetség témakört pedig Szabó János (2018) ragadta meg tanulmányában, mely a tudományos tehetség hat legfontosabb összetevőjét elemezte az egyetemi oktatók szempontjából.

$\mathrm{Az}$ intra-, interperszonális jelenségvilágot ragadja meg Pomázi Imre (2018) „Konfliktuskezelési technikalitás - gazdagodó diák - személyiségeszközök” címü alkotása, Novák Anikó (2018) kortárs magyar aparegényekre koncentráló irodalmi elemzése. Ebbe a témakörbe tartozik továbbá Rudolf Panka (2018) müve is, melyben a testvérkapcsolatokat a biblioterápia oldaláról közelíti meg. Inhóf Orsolya és Szabó János (2018) a személyiség kognitív aspektusát ragadják meg pszichológiai orientációjú vizsgálatukban, mely során az akusztikus ingereknek vizuális keresési feladatra, illetve detekcióra gyakorolt hatását kutatták.

Más Szerzők tanulmányai a tanulás, tanuláskutatás és -fejlesztés témáját ragadták meg. Galambos Petra és Ocsenás Dorottya (2018) írásukban mutatnak rá a zsonglőrködés innovatív, tanulást fejlesztő módszerként való megközelítésére. Szilágyi Gabriella (2018) az online tanulási környezetben megvalósuló önirányított tanulásról írt.

A munkaerőpiaci, illetve vállalati témakörbe sorolható Herpai János (2018) müve, amelyben a (vállalati) csoportmunkában megvalósuló egyéni teljesítmények növelésének White board módszerrel történő lehetőségét mutatja be. Virág Ádám (2018) pedig a szociális szövetkezetek Szabolcs-Szatmár-Bereg megyei helyzetképét vázolja fel. Psenak Péter és Káčer, Ján (2018) kiváló tanulmányukban azt elemzik, hogy Szlovákiában az informatikai ágazatban a munkakereső egyetemi végzettségének szignifikáns hatása van-e a munkaadó választására. Vajon ügyelnek-e a munkaadók a munkaerő kiválasztásánál arra, hogy az egyén milyen egyetemen szerezte a diplomáját? Ugyanolyan végzettséggel rendelkező munkavállalók előnyben részesülnek-e bizonyos egyetemen szerzett diplomával, míg mások nem, ugyanolyan végzettséggel?

Végül annak a reménynek szeretnénk hangot adni, hogy e kiadvány remélhetôen nem pusztán egy pályázati folyamat záró produktuma lesz, hanem a résztvevők számára élethosszan tartó innovatív gondolkodásra és tevékenységre épülő tudományos/üzleti karrier meghatározó sarokköve, emléke is lesz egyben. A Szerzőknek ezért kreatív teljesítményekben, innovációkban gazdag sikeres szakmai életutat kívánunk! A pályázat megvalósítását, s e kiadvány megjelenését lehetővé tevő szerkesztők és mentorok munkáját 
köszöneti illeti. Végül, de nem utolsó sorban hangsúlyozni szeretnénk, hogy a Nemzeti Tehetség Program támogatása rendkívül fontos a felnőttkori, innovációközpontú tehetséggondozást (vö.: Mező és Mező, 2018) megvalósító programok, szervezetek számára.

\section{IRODALOM}

Babik Tamás (2018): Fogyatékosság-specifikus tréningek tartása a „többségi társadalom” tagjai részére. In: Kemény László, Koncz István és Szova Ilona (szerk.): Felkészülés (együtt) a XXI. század kihívásaira. Mentorált fiatalok írásai. Professzorok az Európai Magyarországért Egyesület, Budapest. 6 -24.

Csepregi Csilla (2018): Sajátos nevelési igényü fiatalok továbbtanulási lehetőségei Magyarországon. In: Kemény László, Koncz István és Szova Ilona (szerk.): Felkészülés (együtt) a XXI. század kihívásaira. Mentorált fiatalok írásai. Professzorok az Európai Magyarországért Egyesület, Budapest. 25-40.

Galambos Petra és Ocsenás Dorottya (2018): Zsonglőrködés, mint innovatív, tanulást fejlesztő módszer. In: Kemény László, Koncz István és Szova Ilona (szerk.): Felkészülés (együtt) a XXI. század kihívásaira. Mentorált fiatalok írásai. Professzorok az Európai Magyarországért Egyesület, Budapest. 41-53.

Herpai János (2018): White board módszer, mint lehetőség az egyéni teljesítmény növelésére csoportmunkában. In: Kemény László, Koncz István és Szova Ilona (szerk.): Felkészülés (együtt) a XXI. század kihívásaira. Mentorált fiatalok írásai. Professzorok az Európai Magyarországért Egyesület, Budapest. 54-70.

Inhóf Orsolya és Szabó János (2018): Akusztikus ingerek hatása a vizuális keresési feladatra és a detekcióra. In: Kemény László, Koncz István és Szova Ilona (szerk.): Felkészülés (együtt) a XXI. század kihívásaira. Mentorált fiatalok írásai. Professzorok az Európai Magyarországért Egyesület, Budapest. 71-85.

Mező Ferenc és Mező Katalin (2018): Az innovációra nevelés: a felnőttkori tehetséggondozás egyik sarokpontja. Tehetség, XXVI. évfolyam 2018/2 szám, 14-15.

Novák Anikó (2018): Apaképek és képtelenségek a kommunikáció hiánya a kortárs magyar aparegényekben. In: Kemény László, Koncz István és Szova Ilona (szerk.): Felkészülés (együtt) a XXI. század kihívásaira. Mentorált fiatalok írásai. Professzorok az Európai Magyarországért Egyesület, Budapest. 86-104.

Pomázi Imre (2018): Konfliktuskezelési technikalitás - gazdagodó diák személyiségeszközök In: Kemény László, Koncz István és Szova Ilona (szerk.): Felkészülés (együtt) a XXI. század kihívásaira. Mentorált fiatalok írásai. Professzorok az Európai Magyarországért Egyesület, Budapest. 105-122.

Psenak Péter és Káčer, Ján (2018): A munkakereső egyetemi végzettségének hatása a munkaadó választására. In: Kemény László, Koncz István és Szova Ilona (szerk.): Felkészülés (együtt) a XXI. század kihívásaira. Mentorált fiatalok írásai. Professzorok az Európai Magyarországért Egyesület, Budapest.123-136.

Rudolf Panka (2018): Testvérkapcsolatokról a biblioterápia oldaláról. In: Kemény László, Koncz István és Szova Ilona (szerk.): Felkészülés (együtt) a XXI. század kihívásaira. Mentorált fiatalok írásai. Professzorok az Európai Magyarországért Egyesület, Budapest. 137-150.

Szabó János (2018): A tudományos tehetség hat legfontosabb összetevője az egyetemi oktatók szempontjából. In: Kemény László, Koncz István és Szova Ilona (szerk.): Felkészülés (együtt) a XXI. század kihívásaira. Mentorált fiatalok írásai. Professzorok az Európai Magyarországért Egyesület, Budapest. 151-166. 
Szilágyi Gabriella (2018): Az önirányított tanulás megjelenése az online tanulási környezetben In: Kemény László, Koncz István és Szova Ilona (szerk.): Felkészülés (együtt) a XXI. század kihívásaira. Mentorált fiatalok irásai. Professzorok az Európai Magyarországért Egyesület, Budapest. 167-176.

Virág Ádám (2018): A szociális szövetkezetek Szabolcs-Szatmár-Bereg megyei helyzetképe. In: Kemény László, Koncz István és Szova Ilona (szerk.): Felkészülés (együtt) a XXI. század kihívásaira. Mentorált fiatalok írásai. Professzorok az Európai Magyarországért Egyesület, Budapest. 177-194. 